\title{
WHERE THE COMPACT AND OPEN CITY MEET
}

\section{Inner and Outer Spaces on the Periphery of Aachen North}

\author{
Ilaria Maria Zedda
}

\section{ArchéA}

Among the numerous topics that can be taken as subjects of mapping, that of urban spaces is particularly relevant, since any architecture - even that major work of architecture that is the city in Aldo Rossi's conception ${ }^{1}$ - is essentially a composition of spaces. Today, the mapping of the spaces of the city, which aims at knowledge about them with the goal of guiding design interventions, is as necessary as it is complex, given the ambiguity and controversy that have surrounded the concept of space since modernity. ${ }^{2}$ This ambiguity has been growing since the 19 th century, when the clear separation between city and countryside, historically marked by city walls, was overcome. From then on, the concepts of inside and outside became hybrid, to the point that, by the mid-20th century, the clear organization of traditional spaces (and the concept thereof) fell into oblivion in the name of modernity.

The Department of Spatial Design at the Rheinisch-Westfälische Technische Hochschule (RWTH) Aachen has focused its research on these issues for more than a decade and developed its own method of mapping spaces: the red-blue plan. First introduced in 2015 with the book Par$d i e^{3}{ }^{3}$ the red-blue plan helps visualize the spatial relationships between urban spaces as well as their dedications and the nature of their boundaries. In the last two years, participating in the project ArchéA, which is presented in this volume, offered opportunities for further reflection as well as international exchanges on mapping and mapping methods.

Prior to identifying a suitable area for the second ArchéA design workshop, the RWTH team's research focused, among other things, on studying and mapping spaces in different areas of Aachen using the red-blue plan. This preliminary research, conducted within the cycle of seminars titled ArchéA - ARCHitectural European medium-sized city Arrangement. Kartierung städtischer Räume $e^{4}$ entailed studying and mapping both the city center and different peripheral areas, providing knowledge of the spatial variety and complexity of Aachen's different neighborhoods. Among the different peripheral areas discussed, the great variety of spatial and morphological solutions in the northeastern periphery, around the ancient Roman axis that is now Jülicher Straße, lent itself especially well to an in-depth analysis of several relevant phases in Aachen's modern development. 
The present chapter recounts that academic experience. First, it illustrates the mapping method of the red-blue plan; then, it retraces the main steps in the modern development of the surroundings of Jülicher Straße alongside their main features, considering morphological, spatial, and typological aspects. Moreover, the chapter intends to demonstrate how the in-depth study of the chosen urban fragment, through both figure-ground and red-blue plans ranging from urban to architectural scale, enables a better understanding of morphological and typological issues, as well as an understanding of the Topos, of the specificities of the place and its genius loci. In this context, the red-blue plan helps to produce comprehensive knowledge of the spaces of the city and can therefore be understood as an important precondition for design.

\section{Red and Blue}

Although the concepts of inner space and outer space are considered to be univocally understoodI am in an inner space when I am inside of a building covered and bounded by walls, while I am in outer space when I am outside its built limits ${ }^{5}$ - both concepts will need to be clarified in order to understand the theoretical assumptions underlying the methodology in question. Whereas it is true that being in an outer space means being outside of the building, it is also true that this outer space (outer here meaning uncovered) can be a field at the edge of the village or city as well as a street or a square within the city. Whereas the former case is perceived as an outer exterior space, the latter is instead perceived as an outer inner space. ${ }^{6}$ In other words, interior spaces are to be understood as architectural spaces as long as they are perceived as such by virtue of their proportions, and regardless of whether they are covered or not. Architectural spaces are, therefore, not only covered rooms but also uncovered urban streets, squares, or courtyards.

Based on these premises, the mapping method of the red-blue plan represents interior architectural spaces in red - be they rooms, streets, courtyards, or squares - defined by architectural boundaries, and exterior spaces perceived as outer fields among architectures, both inside and outside of the city, are represented in blue. ${ }^{7}$

As this chapter will show, the contents conveyed by the red-blue plan depend on the scale of the drawings. On a large scale, only two colors are used, namely red for interior architectural spaces and blue for exterior spaces. On a more detailed scale, two different shades of red and blue respectively indicate the level of enclosure (covered-uncovered) and linkage (urbanrural) of each space. Dark red is used for buildings, when covered and enclosed by walls; light red for uncovered architectural spaces, like courtyards, small squares, or narrow streets; light blue for spaces perceived as urban fields, such as broad roads or big squares, that are still linked to and link other architectures; and, finally, dark blue for landscape fields, which normally mark the borders of the city. Moreover, at this level of detail, the plan begins to communicate further information about the nature of the boundaries between contiguous spaces, as can be seen in Figure 5.3. There are boundaries that actively define different spatialities, such as walls, and boundaries that do it passively instead, that is, structurally rather than physically, such as parcels. Whereas active boundaries mark a perceivable change among contiguous spaces, passive ones mark an invisible but no less significant difference, namely their ownership. In the red-blue plan, white lines indicate active boundaries and black lines indicate passive ones.

Finally, on a more detailed scale, as can be seen in Figure 5.4, two different shaded areas visualize different dedications of spaces, that is, whether these spaces are exclusive or inclusive. Exclusive spaces - those solely for private use - are represented with a white shaded area, and inclusive spaces - those accessible to third parties - are represented with a black shaded area. ${ }^{8}$ 


\section{Aachen North and Jülicher Straße}

Before discussing the use of red-blue plans in the specific case of the area around Jülicher Straße analyzed in the seminar and presented in this chapter, it would be helpful to clarify some historical issues in order to understand its current configuration.

Figure 5.1 shows which position the analyzed area occupies in relation to the city center of Aachen. Within its borders, framed in red in the figure-ground plan, Jülicher Straße corresponds to the diagonal axis that runs from the path of the former outer city wall toward the northeastern city borders.

One of the most outstanding aspects of this axis is its history: it dates back to Roman times, ${ }^{9}$ when it served as a link to the nearby center of Jülich and then Cologne - a role

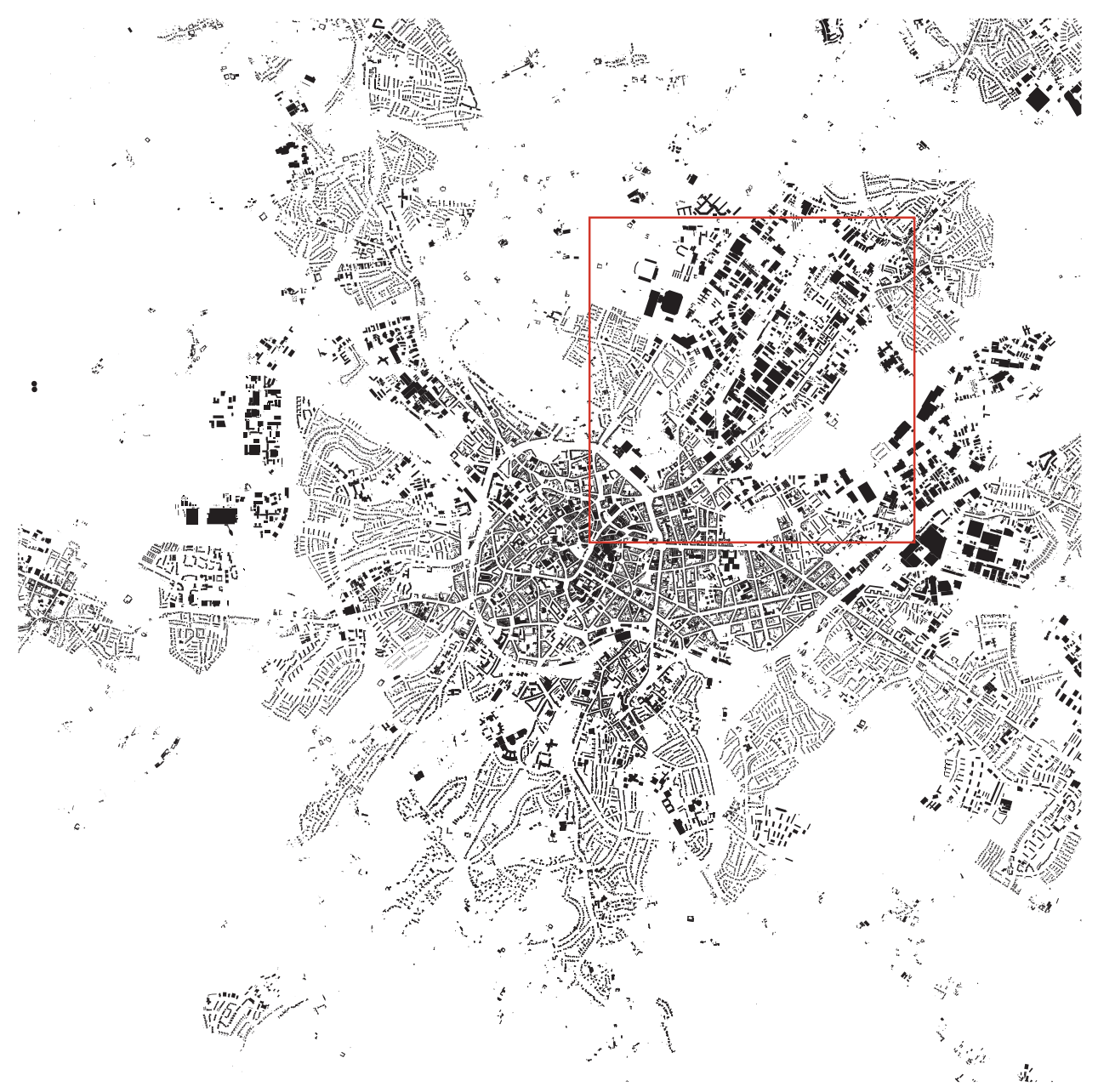

FIGURE 5.1 Figure-ground plan of Aachen (original scale 1:10.000) where the area around Jülicher Straße is framed in red. Drawing made during the Seminar ArchéA ARCHitectural European Medium-sized city Arrangement. Kartierung städtischer Räume (last edited in Winter Semester 2019/20) Original digital source: C) OpenStreetMap contributors (CC BY-SA 2.0 www.openstreetmap.org/copyright) 
that it maintained throughout the Middle Ages and early modern times. Especially from the 19th century onwards, its surroundings underwent major changes, turning into an industrial settlement.

The earliest industrial developments, which made Aachen one of Germany's leading industrial cities in the first half of the century, ${ }^{10}$ were promoted during the years of Napoleonic rule ${ }^{11}$ and significantly changed the surroundings of Jülicher Straße in the first half of the century. More remarkable construction initiatives followed from then on, beginning with the blocks in Rehmviertel, which extended this part of Aachen beyond the former Kölntor (gate of Cologne). The blocks in Rehmviertel, built from 1860 onwards, are defined by two parallel streets and frame a central, regular rectangular square, thus offering an example of classicist planning in the Gründerzeit. ${ }^{12}$

By the time the Rehmviertel was completed in 1910, several construction initiatives had been undertaken, including the realization of the new freight station Aachen North in 1875, which directly overlooked Jülicher Straße. Thanks to the favorable location and the presence of the new station, several industries were established in this area in the following years, thus making it necessary to provide the district with enough houses for the working class. Among these housing complexes are two blocks delimiting Joseph-von-Görres Straße, dating back to the 1920s - remarkable examples of reform architecture in Aachen. Reform architectures, built in several European cities at that time, were conceived mainly for workers in the nearby industries and can be understood as a first attempt to remedy the shortcomings of the 19th-century block without renouncing the typology, namely the organization of its buildings around a courtyard separated from the street.

Figure 5.2 refers to the development of the surroundings of Jülicher Straße between 1910 and 1978. There, one can see that the most intense construction activities occurred from the 1950s onwards. Whereas the earliest efforts after Second World War concentrated on repairing the damages the district suffered (especially in its southern part close to the Heinrichsallee), later planning initiatives concentrated on urban expansion and infrastructural improvement. The construction of Europaplatz in the late 1950s (the big traffic circle that can be seen at the bottom of Figure 5.3) completely changed the role of this part of the city, turning it into the triumphal modern entrance to Aachen from the motorway to Cologne. The district was thus transformed, within little more than a century, from countryside to early industrial neighborhood and, finally, to important industrial and infrastructural pole.

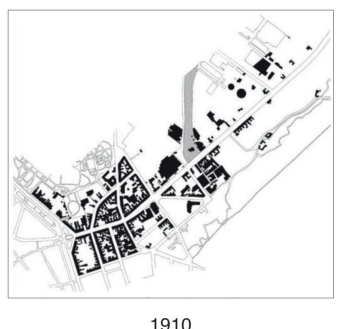

1910

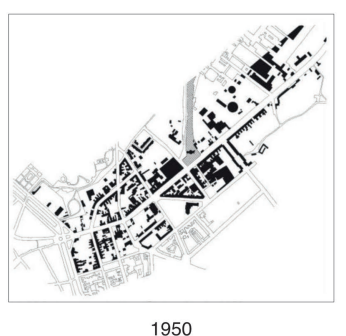

1950

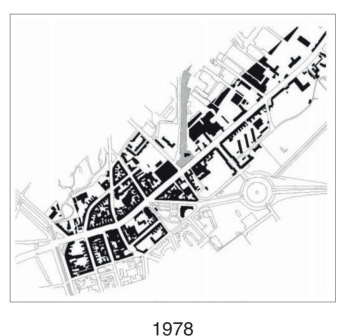

1978

FIGURE 5.2 Development of the surroundings of Jülicher Straße between 1910 and 1978. Figureground plans from: Curdes, G. 1999. Die Entwicklung des Aachener Stadtraumes: der Einfluß von Leitbildern und Innovationen auf die Form der Stadt. Dortmund: Dortmunder Vertrieb für Bau- und Planungsliteratur, pp. 144-145. (C) Gerhard Curdes. 
This part of Aachen is exemplary of modern peripheral expansion in medium-sized European cities, where architectures dating from different historical phases coexist, and whose boundaries - unlike those of metropolitan suburbs that seamlessly incorporate neighboring centers - directly meet and melt with the surrounding countryside.

\section{From Red to Blue: A Path along Jülicher Straße}

Figure 5.3 was drawn during the seminar ArchéA and maps the urban spaces around Jülicher Straße in their current configuration using the method of the red-blue plan. At this scale (plan segment Stadt, or city), the red city of the inner, architectural spaces, which

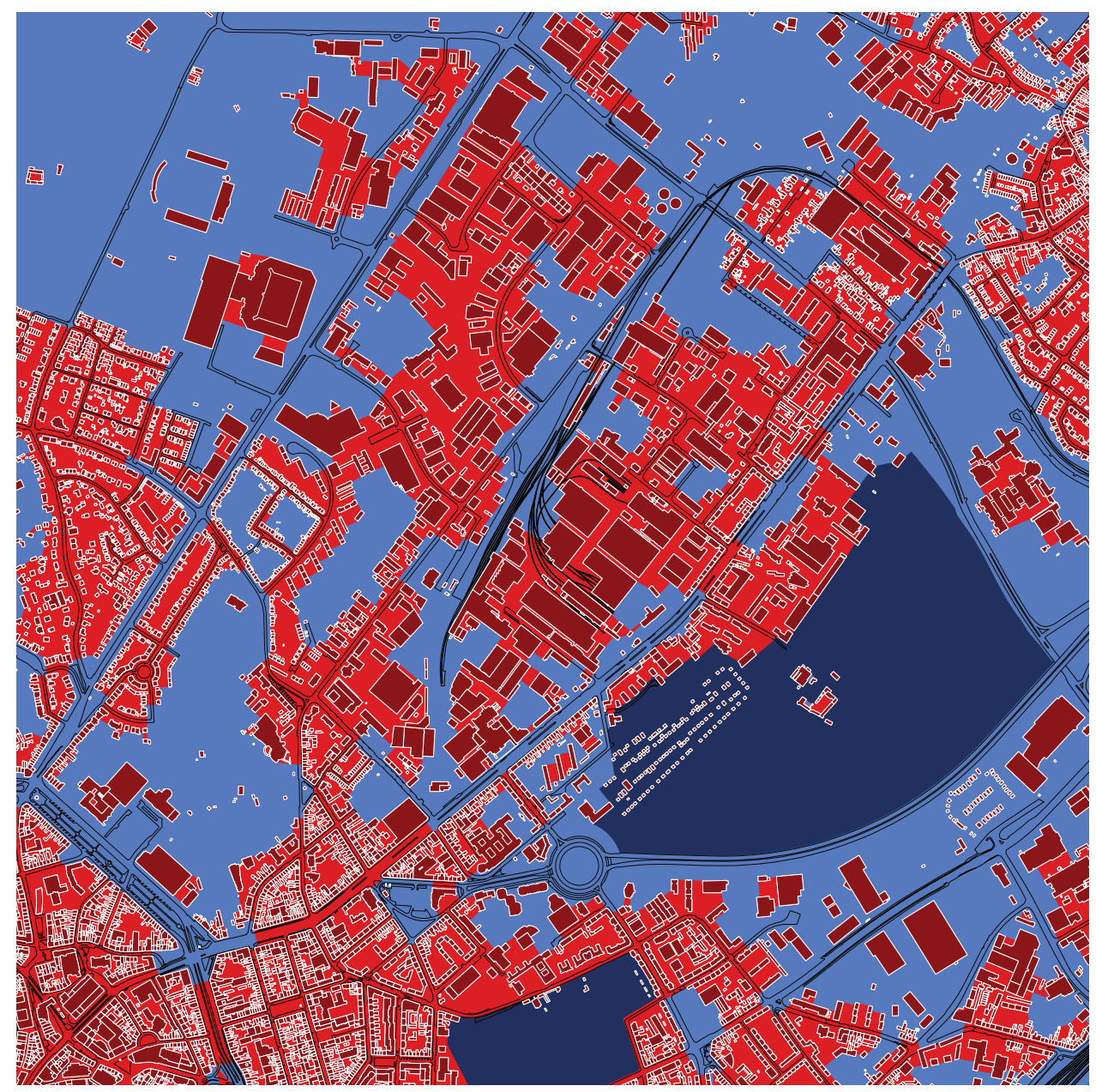

FIGURE 5.3 Red-blue plan of the area around Jülicher Straße, plan segment Stadt/City (original scale 1:5000). Drawing made by the students of the Seminar ArchéA - ARCHitectural European Medium-sized city Arrangement. Kartierung städtischer Räume, Winter Semester 2019/20 (Authors: Betsa A., Lee K.-M., Liao Y., Schumacher F., Scurtu T.) and further edited by the author (2021). 
corresponds to the urban blocks closest to the former city wall, gradually makes room for a mixture of red and blue, where architectural spaces (red) mix with urban fields (light blue) and landscape fields (dark blue). A first important break in the continuity of the (red) historical city can be seen at the point where Jülicher Straße branches off to the southwest and merges with Heinrichsallee, intersecting with the path of the ancient outer city wall. As one moves northeast, interruptions in the continuity of red come with increasing frequency, until the point where red is the exception in a dominant blue, where spaces destined for infrastructures and huge industrial parking lots prevail over architectural spaces.

Given the complexity of current urban situations, it is necessary to think about what could be the most appropriate solution for creating an adequate balance of the compact city and the open city, of red and blue, of interior and exterior spaces. In this effort, it may be useful to deepen the study of those parts of the existing urban fabric where the encounter between these two paradigms has occurred spontaneously, in order to reflect on the critical issues as well as the potential of these scenarios. One could even rely on these encounters to develop suggestions for the current practice of designing urban spaces.

Along Jülicher Straße, this spontaneous encounter can be identified in the situation at the corner of Jülicher- and Joseph-von-Görres Straße. As a result, this specific area was chosen for further investigations at architectural scale during the seminar (plan segment Stadt und Haus, or city and house). Within the boundaries of this plan (Figure 5.4), which correspond to Jülicher Straße to the north and Europaplatz to the south, two open blocks face the opposite sides of Joseph-von-Görres Straße. In both of these blocks, the front of Jülicher Straße is lined with Gründerzeit architectures, which can be ascribed to the typology of the Dreifensterhaus (three-windowed house) typical of the North Rhine-Westphalia region. ${ }^{13}$ These are normally on three or four levels and can be recognized by their façades with regular axes and side entrances. In this case, the buildings on the left of the plan segment (Figure 5.4b) are variants of the type - one of which has, for example, four windows instead of three and an equal number of axes in the facade. They have commercial facilities on the ground floor and buildings both on the side of and inside the private courtyard. Behind these regular façades, the courtyards of the houses are relatively small and for private use.

The architectures shown in Figure 5.4c that face Joseph-von-Görres-Straße are markedly different. These are the two examples of reform blocks mentioned in the previous section, whose uniform fronts open in two big passages facing the public street, thus allowing access to the wide, collective interior of the block. This openness is quite typical for reform blocks, where the inner space of the courtyard is left mostly empty and communication between courtyard and street was not avoided but rather encouraged. However, in both reform blocks on Joseph-von-Görres-Straße the openness is somehow excessive. Indeed, their built perimeter remained incomplete and their southern parts are overly open to the outer public space. The interior of the block, traditionally an inner, architectural space, mixes with outer urban fields. Consequently, their courtyards are mostly blue. In addition to the unclear nature of these blocks' boundaries, this openness made it possible for solitary buildings to be built inside of their courtyards, such as the Zeilenbauten (line buildings) built after the Second World War in the courtyard eastern of Joseph-von-Görres Straße (Figure 5.4d). This, in turn, only increases the current confusion about boundaries, destinations, and clearly recognizable typologies.

The plan segment city and house conveys information on the spatiality of streets and courtyards. The deepening of its legend and the use of different shaded areas also let it show more typological issues, such as the distribution of accesses, organization of the rooms, 

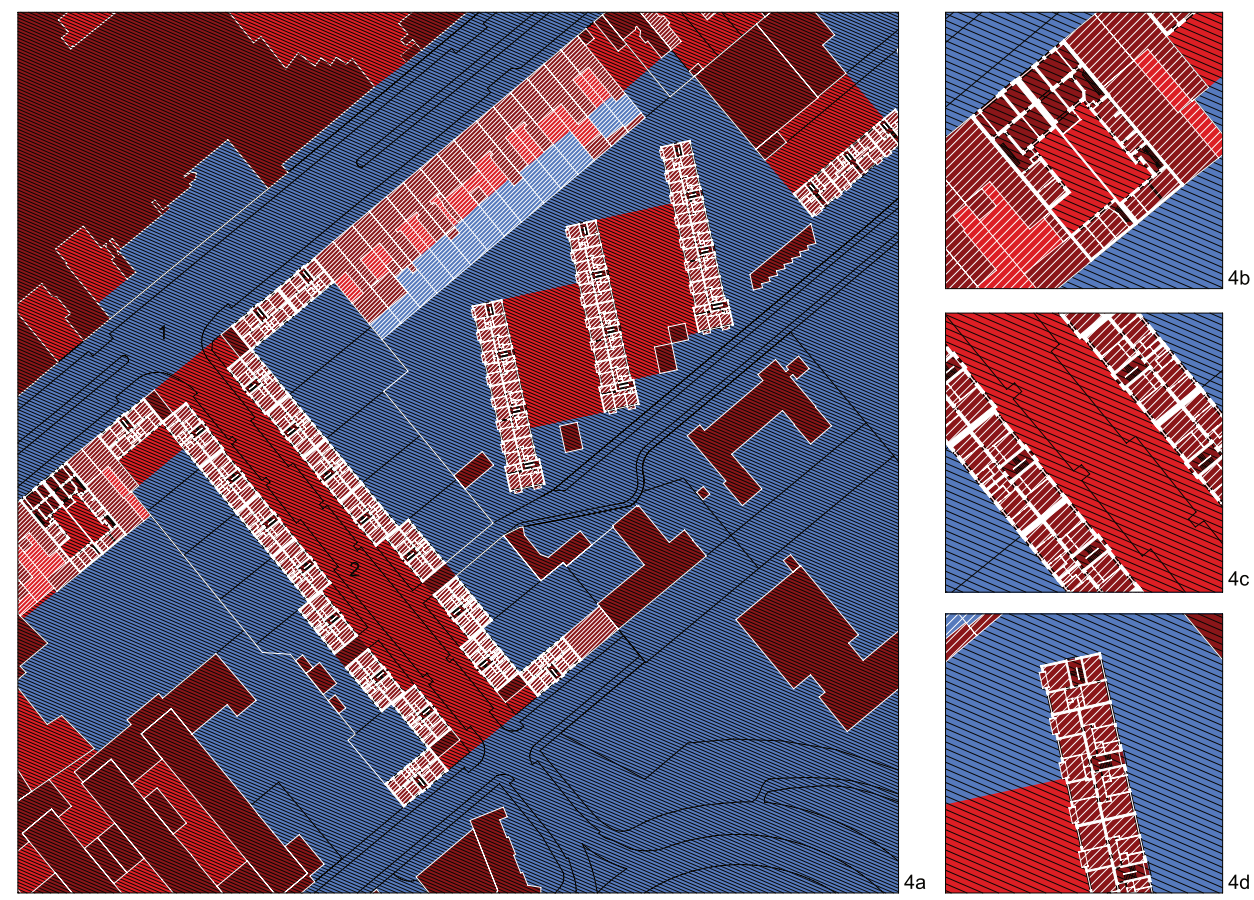

FIGURE 5.4 a-d: (Clockwise, starting from figure 4a on the left): Red-blue plan of Jülicher Straße (marked with "1" in the figure), corner with Joseph-von-Görres Straße (marked with "2" in the figure): plan segment Stadt und Haus/City and house (original scale 1:333). Alongside the spatial differences marked in the plan by the different shades of red and blue and by black and white lines, as in plan segment Stadt, this plan also provides information on the dedication of spaces (inclusive-exclusive) through different shaded areas (black-white). On the right side of the plan segment (Figure 4a) are three different zooms within the plan (Figures $4 \mathrm{~b}-4 \mathrm{~d}$ ). From top to bottom: houses of the Gründerzeit (built by the end of the 19th century), houses in the reform blocks facing Joseph-von-Görres Straße (built in the1920s), and apartments in one of the three Zeilenbauten built (1950s) inside the courtyard of the eastern reform block, close to Europaplatz. Drawing made by the students of the Seminar ArchéA - ARCHitectural European Medium-sized city Arrangement. Kartierung städtischer Räume, Winter Semester 2019/20 (Authors: Lee K.-M., Schumacher F., Scurtu, T.) and further edited by the author (2021). Redrawn after: Planmaterial der Bauaktenkammer Aachen.

nature of the boundaries, and dedication of the different spaces. In other words, the red-blue plan not only visualizes the spatial relations between covered and uncovered architectural spaces but also helps us understand how these spaces are used, how they relate to one another, and how they communicate with the exterior urban fields and unbound landscapes. It thus visualizes spatial organization, relationships, boundaries, and dedications.

\section{Streets without Architecture}

Due to its limited extension, the plan segment city and house, previously described, is not sufficient to summarize the great variety and complexity of spatial situations that can be 
encountered within the entire area around Jülicher Straße. Nonetheless, even from this relatively small fragment, it is possible to deduce some spatial problems that are characteristic of modern urban developments, where streets and squares lose their traditional role as spaces for meeting and exchange and become instead spaces of mere transit and movement. This legacy of the modern paradigm of the car-friendly city is lamented by the German architect and architectural theorist Fritz Neumeyer. In this respect, he observes how these spatial changes have profoundly affected the historical relation between the buildings and the street, withdrawing the former from the latter. ${ }^{14}$ Neumeyer argues that the result of this condition "is a cityscape of streets without architecture," further remarking that the modern city "transforms the city of closed squares into the city of open crossroads and green strips, in which buildings, isolated from each other, remain passive objects in the background."15

Given the dissolution of the historical boundaries of the street and the presence of architectural objects, there is a general confusion about what is public and what is private. Fences are needed to delimit the latter from the former, performing the erstwhile duty of walls. In this ambiguous state of things, the modern city and its floating space mix with (and prevail over) the traditional one and its architectural spaces.

"Everything interior ... becomes exterior," writes the German architect Uwe Schröder about these spatial problems of the "open" city of the Modern, where - as he further remarks "linkages between, boundaries, and in particular dedication of specific spaces are now left undefined."16

The lack of clear boundaries and dedications, lamented by Schröder, combined with the present condition of many "streets without architecture," criticized by Neumeyer, generates great confusion and makes it impossible to recognize oneself in any of these spaces. This is the current condition of many European peripheries, and those of Aachen are no exception.

In the area around Jülicher Straße, the prevalence of exclusive spaces over inclusive ones, as well as the prevalence of exterior spaces over interior ones, increases as one moves toward the periphery, where industries with their huge parking lots prevail over residences. Furthermore, despite the recent conversion of some of these industrial structures into places for cultural life and the community, ${ }^{17}$ this part of the city still lacks adequate inclusive open spaces for meeting and gathering.

What underlies these problems is a lack of proper balance between exterior and interior spaces, which is due to the lack of an overarching plan for the area's urban development. For the same reasons, the district lacks high-quality public spaces, which are the basis of urbanity as argued by the Italian architect Antonio Monestiroli in his lecture L'arte di costruire le città (The Art of Building Cities). According to him, such spaces are indispensable for enabling citizens' identification with their city, as well as meeting and socialization, much like the squares in historical cities. ${ }^{18}$

The spatial problems of Jülicher Straße are the spatial problems of many other European peripheries, which the German architect and urban planner Thomas Sieverts describes as cities without cities - or cities "in between," if one tries to translate the German term Zwischenstadt literally ${ }^{19}$ - which are "neither city nor landscape," ${ }^{20}$ in a constant process of growth and change.

As proved by this brief final excursus, mapping urban spaces with red-blue plans enables a critical analysis of the different spaces of the city, highlighting issues that ought to be solved with targeted design interventions. Obviously, it is not a question of re-proposing the spatiality of the traditional city in these contemporary peripheries. It is rather a matter of developing spatial solutions appropriate to them, that do not ignore but instead take the modern city into account and involve it in a new system of spatial relations, where buildings 
are not only nebeneinander (next to each other), but again miteinander (with each other), ${ }^{21}$ where both interior and exterior urban spaces acquire fine contours again, where nature and architecture don't just randomly mix but clearly relate and where streets are given back their architectures.

\section{Notes}

1 Rossi, A. 1966. L'architettura della città. Padova: Marsilio [Consulted English translation: Rossi, A. 1982. The architecture of the city. Cambridge, MA and London: The MIT Press., 29]

2 See contribution in this volume by Schröder, U. 2021. A Spatial Understanding for Architecture and the City, 7.

3 Schröder, U. 2015. Pardié. Konzept für eine Stadt nach dem Zeitregime der Moderne/A Concept for a City after the Time Regime of Modernity. Cologne: Verlag der Buchhandlung Walter König.

4 ArchéA - ARCHitectural European medium-sized city Arrangement. Kartierung städtischer Räume (Mapping urban spaces): Seminar held in the academic year 2019/2020 at the RWTH Aachen, Department of Spatial Design. Head of the Department: Prof.-Univ. Dipl.-Ing. Uwe Schröder, Lecturer: M.Sc. Ilaria Maria Zedda.

5 See contribution in this volume by Schröder, U. 2021: A Spatial Understanding for Architecture and the City, 8.

6 Schröder, U. 2015. Pardié, 9.

7 Schröder, U. 2015. Pardié, 7-8.

8 Schröder, U. 2015. Pardié, 13-14.

9 On Roman settlements in Aachen's region, see Curdes, G. 1999. Die Entwicklung des Aachener Stadtraumes: der Einfluß von Leitbildern und Innovationen auf die Form der Stadt. Dortmund: Dortmunder Vertrieb für Bau- und Planungsliteratur, $11 \mathrm{ff}$.

10 This leading position, however, was short-lived and soon lost by the early 20 th century. See Curdes, G. 1999. Die Entwicklung des Aachener Stadtraumes, 74-79.

11 Napoleonic rule in Aachen lasted from 1792 to 1814.

12 The term Gründerzeit refers to the period of rapid industrial development in Germany during the second half of the 19th century, especially following the unification of the country in 1871 . On Gründerzeit developments in Aachen, see Curdes, G. 1999. Die Entwicklung des Aachener Stadtraumes, 79-86.

13 See Eberstadt, R.1903. Rheinische Wohnverhältnisse und ihre Bedeutung für das Wohnungswesen in Deutschland Nebst 17 Grundrissen deutscher Kleinwohnungsgebäude. Jena: Fischer Verlag, 11-19.

14 Neumeyer, F. 2014. Städtischer Raum. Ein architektonisches Phänomen. In: Stadt der Räume. Interdisziplinäre Überlegungen zu Räumen der Stadt, ed. Denk A. and Schröder U. Tübingen/ Berlin: Wasmuth, 98.

15 Neumeyer, F. 2014. Städtischer Raum. Ein architektonisches Phänomen. In: Stadt der Räume. Interdisziplinäre Überlegungen zu Räumen der Stadt, ed. Denk A. and Schröder U. Tübingen/Berlin: Wasmuth, 95-100. Quote translated by the author from p. 98 ["Ein Stadtbild von Straßen ohne Architektur ist die Folge. Die moderne Stadt verwandelt die Stadt der geschlossenen Plätze in die Stadt der offenen Straßenkreuzungen und Grünstreifen, an denen die Bauten, isoliert voneinander, als passive Objekte im Hintergrund bleiben"].

16 Schröder U. 2015. Pardié, 9.

17 Among these projects, it is worth mentioning the 1991 conversion of the former umbrella factory Brauer on Jülicher Straße into the museum Ludwig Forum für Internationale Kunst (Ludwig Forum for International Art), which established an important cultural pole outside of the city's historical perimeter.

18 Monestiroli, A. 2008. Lezione V: L'arte di costruire le città. Chapter 5 in: La metopa e il triglifo, 4th edition, Roma Bari: Laterza, 65-80.

19 Sieverts, T. 2003. Cities Without Cities. An Interpretation of the Zwischenstadt (1st English ed.) London: Spoon Press and New York: Routledge [First published in German, 1997. Zwischenstadt. Zwischen Ort und Welt, Raum und Zeit, Stadt und Land. Bauwelt Fundamente 118. Braunschweig, Wiesbaden: Vieweg].

20 Sieverts, T. 2003. Cities Without Cities, 3. 
21 Sieverts, T. in conversation with Binotto W., Garkisch A., and Jessen A.: Dezentrale Dichte, Dortmunder Architekturtage 2020, Call 3. Symposium. June 18, 2020. Available at: https://www.youtube. $\mathrm{com} /$ watch? $\mathrm{v}=$ bv8s6c7SeRw (min. 12:30-12:35, link accessed on January 5, 2021).

\section{Bibliography}

Curdes, G. 1999. Die Entwicklung des Aachener Stadtraumes: der Einfluß von Leitbildern und Innovationen auf die Form der Stadt (Stadt -Raum - Innovation, Bd.3) Dortmund: Dortmunder Vertrieb für Bau- und Planungsliteratur.

Eberstadt, R. 1903. Rheinische Wohnverhältnisse und ihre Bedeutung für das Wohnungswesen in Deutschland Nebst 17 Grundrissen deutscher Kleinwohnungsgebäude. Jena: Fischer Verlag.

Monestiroli, A. 2008. La metopa e il triglifo. 4th edition, Roma/Bari: Laterza [First edition: 2002].

Neumeyer, F. 2014. Städtischer Raum. Ein architektonisches Phänomen. In: Stadt der Räume. Interdisziplinäre Überlegungen zu Räumen der Stadt, eds. Denk A. and Schröder U. Tübingen/ Berlin: Wasmuth, pp. 95-100.

Rossi, A. 1966. L'architettura della città. Padova: Marsilio.

Schröder, U. 2015. Pardié. Konzept für eine Stadt nach dem Zeitregime der Moderne / A Concept for a City after the Time Regime of Modernity. Cologne: Verlag der Buchhandlung Walter König.

Sieverts, T. 2003. Cities Without Cities. An Interpretation of the Zwischenstadt. [1st English ed.] London: Spoon Press and New York: Routledge [First published in German, 1997. Zwischenstadt. Zwischen Ort und Welt, Raum und Zeit, Stadt und Land. Bauwelt Fundamente 118. Braunschweig, Wiesbaden: Vieweg]. 